\title{
Sex effects on net protein and energy requirements for growth of Saanen goats
}

\author{
A. P. Souza, ${ }^{*}$ N. R. St-Pierre, $†$ M. H. R. M. Fernandes, ${ }^{*}$ A. K. Almeida, ${ }^{*}$ J. A. C. Vargas, ${ }^{*}$ K. T. Resende, ${ }^{*}$ \\ and I. A. M. A. Teixeira*1 \\ *Department of Animal Sciences, Universidade Estadual Paulista, Jaboticabal, SP 14884-900, Brazil \\ †Department of Animal Sciences, The Ohio State University, Columbus 43201
}

\begin{abstract}
Requirements for growth in the different sexes remain poorly quantified in goats. The objective of this study was to develop equations for estimating net protein $\left(\mathrm{NP}_{\mathrm{G}}\right)$ and net energy $\left(\mathrm{NE}_{\mathrm{G}}\right)$ for growth in Saanen goats of different sexes from 5 to $45 \mathrm{~kg}$ of body weight (BW). A data set from 7 comparative slaughter studies (238 individual records) of Saanen goats was used. Allometric equations were developed to determine body protein and energy contents in the empty BW (EBW) as dependent variables and EBW as the allometric predictor. Parameter estimates were obtained using a linearized (log-transformation) expression of the allometric equations using the MIXED procedure in SAS software (SAS Institute Inc., Cary, NC). The model included the random effect of the study and the fixed effects of sex (intact male, castrated male, and female; $\mathrm{n}=94,73$, and 71 , respectively), EBW, and their interactions. Net requirements for growth were estimated as the first partial derivative of the allometric equations with respect to EBW. Additionally, net requirements for growth were evaluated based on the degree of maturity. Monte Carlo techniques were used to estimate the uncertainty of the calculated net requirement values. Sex affected allometric relationships for protein and energy in Saanen goats. The allometric equation for protein content in the EBW of intact and castrated males was $\log _{10}$ protein $(\mathrm{g})=2.221( \pm 0.0224)$ $+1.015( \pm 0.0165) \times \log _{10}$ EBW $(\mathrm{kg})$. For females, the relationship was $\log _{10}$ protein $(\mathrm{g})=2.277( \pm 0.0288)$ $+0.958( \pm 0.0218) \times \log _{10}$ EBW $(\mathrm{kg})$. Therefore, $\mathrm{NP}_{\mathrm{G}}$ for males was greater than for females. The allometric equation for the energy content in the EBW of intact males was $\log _{10}$ energy $(\mathrm{kcal})=2.988( \pm 0.0323)+1.240$ $( \pm 0.0238) \times \log _{10}$ EBW $(\mathrm{kg})$; of castrated males, $\log _{10}$ energy $(\mathrm{kcal})=2.873( \pm 0.0377)+1.359( \pm 0.0283) \times$
\end{abstract}

Received August 19, 2016.

Accepted February 4, 2017.

${ }^{1}$ Corresponding author: izabelle@fcav.unesp.br $\log _{10}$ EBW (kg); and of females, $\log _{10}$ energy $(\mathrm{kcal})=$ $2.820( \pm 0.0377)+1.442( \pm 0.0281) \times \log _{10} \mathrm{EBW}(\mathrm{kg})$. The $\mathrm{NE}_{\mathrm{G}}$ of castrated males was greater than that of intact males and lower than that of females. Using degree of maturity for estimating $\mathrm{NP}_{\mathrm{G}}$ and $\mathrm{NE}_{\mathrm{G}}$, we could remove the differences between sexes. These results indicate that $\mathrm{NP}_{\mathrm{G}}$ and $\mathrm{NE}_{\mathrm{G}}$ differ among sexes in growing Saanen goats, and this difference should be accounted for by feeding systems. Including the degree of maturity as predictor cancels out those differences across sexes in protein and energy requirements.

Key words: allometry, comparative slaughter, degree of maturity, mature weight, nutrient requirement

\section{INTRODUCTION}

Annual world production of fresh goat milk has risen by about $60 \%$ in the last $20 \mathrm{yr}$ (FAOStat, 2015). To meet the demand for goat dairy products while improving the efficiency of the production system, goats must be fed a balanced diet to supply the nutrients and energy required for optimal production.

Sex is one of several variables that affect the rate of body protein and fat deposition in different species (Geay, 1984; Herring et al., 2013). The effects of sexual hormones on the development of muscle and adipose tissue have been extensively studied. Therefore, it is expected that the differences in body composition between sexes would affect the nutritional requirements for growth (NRC, 2007). However, the effect of the sex of an individual on the requirements for growth remains poorly quantified in goats. The most recent recommendations for energy and protein requirements for goats (NRC, 2007) did not account for differences in the composition of gain between sexes. Our hypothesis is that the sex of an individual has an effect on the net protein and net energy requirements for growth in dairy goats.

Results from multiple comparative slaughter studies conducted at our institution were used to quantify the effect of sex on the net protein and energy requirements 
of growing goats. The objective of this study was to develop equations for estimating net protein $\left(\mathbf{N P}_{\mathbf{G}}\right)$ and $\mathrm{NE}_{\mathrm{G}}$ required for growth in Saanen goats of different sexes with BW between 5 and $45 \mathrm{~kg}$.

\section{MATERIALS AND METHODS}

\section{Data Set}

A data set was assembled from 7 comparative slaughter studies including 238 individual records of Saanen goats (Gomes, 2011; Bompadre et al., 2014; Medeiros et al., 2014; Almeida et al., 2015a,b; Ferreira et al., 2015; Figueiredo et al., 2016a,b; Table 1). The studies were conducted at the Universidade Estadual Paulista (Jaboticabal, SP, Brazil) with intact males, castrated males, and female goats $(\mathrm{n}=94,73$, and 71 , respectively). Empty BW (EBW) was calculated as the difference between BW at slaughter and the contents of the gastrointestinal tract and bladder. Total body protein and energy content of each animal in all experiments were calculated from the chemical composition of the body, where the amounts of protein (expressed as $\mathrm{g} / \mathrm{kg}$ ) and energy (expressed as $\mathrm{kcal} / \mathrm{kg}$ ) were obtained from whole-body composition multiplied by the EBW (expressed in $\mathrm{kg}$ ). Body protein content was obtained by $\mathrm{N}$ analysis performed via Dumas combustion using a Leco FP-528LC analyzer (Leco Corp., St. Joseph, MI; Etheridge et al., 1998), and body energy content using an adiabatic calorimetric bomb under protocols described in each of the published sources. A summary of the body composition data used in this study is reported in Table 2.

Only animals fed ad libitum were included in the current study. The protein and energy composition of the diets fed to the study animals ranged from 137 to $204 \mathrm{~g} / \mathrm{kg}$ of $\mathrm{CP}$ and 2.4 to $2.7 \mathrm{Mcal} / \mathrm{kg}$ of ME. In all trials, ME was estimated from digestible energy measured by total fecal collection, with energy lost to gaseous products of digestion calculated using the equation of Blaxter and Clapperton (1965). The ratio of roughage to concentrate ranged between 25:75 and 50:50. All procedures used across studies were reviewed by the University's Animal Care Committee (Comissão de Ética e Bem-Estar Animal, CEBEA; Universidade Estadual Paulista, Jaboticabal, Brazil).

\section{Statistical Analyses and Parameter Estimation}

Estimation of $\boldsymbol{E} \boldsymbol{B} \boldsymbol{W}$. Regression equations were developed for estimating EBW from BW. The mixed model included the fixed effects of sex (female, castrated male, or intact male) and phase (suckling or weaned), and the study as a random effect.

Allometric Equations. The methods used to estimate $\mathrm{NP}_{\mathrm{G}}$ and $\mathrm{NE}_{\mathrm{G}}$ were similar to those described by Lofgreen and Garrett (1968). Allometric equations were developed for body protein and energy contents in the EBW. Statistically, the allometric equation can take 2 forms: untransformed (i.e., native scale) and logtransformed to linearize the model. In our application, the native scale results in the following nonlinear mixed model:

$$
Y_{i j k}=\dot{B}_{0_{i}} W_{i j k}^{\dot{B}_{1_{i}}}+\dot{s}_{j}+\dot{e}_{i j k}
$$

where $Y_{i j k}$ is the value of the dependent variable (either total energy in the EBW expressed as kilocalories, or total protein expressed as grams in the EBW) for the $k$ th animal of the $i$ th sex in the $j$ th study, $W_{i j k}$ is the EBW of the $k$ th animal of the $i$ th sex in the $j$ th study,

Table 1. Summary of characteristics of the 7 studies used to assemble the data set

\begin{tabular}{|c|c|c|c|c|c|}
\hline Study & Sex & Phase $^{1}$ & $\mathrm{n}^{2}$ & BW (kg) & $\mathrm{EBW}^{3}(\mathrm{~kg})$ \\
\hline Gomes (2011) & Intact male & Weaned & 18 & 30.0 to 51.0 & 19.4 to 41.7 \\
\hline \multirow[t]{3}{*}{ Bompadre et al. (2014) } & Castrated male & Suckling & 10 & 4.7 to 16.7 & 3.9 to 13.7 \\
\hline & Intact male & Suckling & 19 & 4.7 to 16.5 & 3.9 to 12.8 \\
\hline & Female & Suckling & 18 & 4.6 to 16.3 & 3.5 to 13.4 \\
\hline Medeiros et al. (2014) & Intact male & Suckling & 23 & 5.1 to 21.6 & 4.9 to 17.5 \\
\hline \multirow[t]{3}{*}{ Almeida et al. (2015a,b) } & Castrated male & Weaned & 16 & 27.8 to 47.4 & 21.7 to 39.7 \\
\hline & Intact male & Weaned & 14 & 27.6 to 46.6 & 21.3 to 39.7 \\
\hline & Female & Weaned & 17 & 27.4 to 44.9 & 23.1 to 38.2 \\
\hline Ferreira et al. (2015) & Castrated male & Weaned & 27 & 20.6 to 35.5 & 15.6 to 30.3 \\
\hline \multirow{3}{*}{ Figueiredo et al. (2016a) } & Castrated male & Weaned & 20 & 15.3 to 32.5 & 13.1 to 26.4 \\
\hline & Intact male & Weaned & 20 & 15.7 to 34.0 & 12.8 to 28.3 \\
\hline & Female & Weaned & 18 & 14.8 to 31.7 & 11.9 to 26.3 \\
\hline Figueiredo et al. (2016b) & Female & Weaned & 18 & 29.5 to 46.0 & 20.8 to 40.4 \\
\hline
\end{tabular}

${ }^{1}$ Suckling refers to goats that were fed milk and solid diet; weaned refers to goats that were fed just solid diet.

${ }^{2}$ Total number of records from the study.

${ }^{3} \mathrm{EBW}=$ empty BW. 
$\dot{B}_{0_{i}}$ and $\dot{B}_{1_{i}}$ are parameters to be estimated for each of the 3 sexes, $\dot{s}_{j}$ is the random effect of the $j$ th study $\sim N\left(0, \sigma_{s}^{2}\right)$, and $\dot{e}_{i j k}$ is the residual error $\sim N\left(0, \sigma_{e}^{2}\right)$.

The allometric portion of model [1] (i.e., the first term on the right-hand side) can be linearized through a log-transformation, resulting in the following statistical model:

$$
\log Y_{i j k}=B_{0_{i}}+B_{1_{i}} \log W_{i j k}+s_{j}+e_{i j k},
$$

where $Y_{i j k}$ and $W_{i j k}$ are as previously defined, $B_{0_{i}}$ and $B_{1_{i}}$ are parameters to be estimated for each of the sexes $i, s_{j}$ is the random effect of the $j$ th study $\sim N\left(0, \sigma_{s}^{2}\right)$, and $e_{i j k}$ is the residual error $\sim N\left(0, \sigma_{e}^{2}\right)$.

The "dot" symbol was used in model [1] to make it clear that although the $B$ parameters are mathematically equivalent in both models, their estimates are not the same statistically. Both models include a random effect of the study to account for systematic differences between studies (St-Pierre, 2001). The NLINMIX macro of SAS software (SAS Inst. Inc., Cary, NC; version 9.4) was used for fitting model [1], whereas the MIXED procedure was used to fit model [2]. Model [1] assumes that the residual errors are additive in the native scale. That is, their variance is homogeneous with respect to $W$. In contrast, model [2] that assumes additive errors in the transformed (i.e., log) scale, which implies errors that are multiplicative and variances that are proportional to $W$ in the native scale. Therefore, choosing the model that is best for a given set of records should be determined by the pattern of the standardized conditional residuals. For all variables that we analyzed, the pattern of residuals was clearly more homogeneous with model [2] than with model [1]. Therefore, model [2] was used to estimate parameters and conduct significance tests. Outliers were removed when their normalized residuals were $>|3|$. For body protein, 3 data points were removed; for body fat and body energy, 2 data points each were removed. The outliers were from 3 different studies (Bompadre et al., 2014; Almeida et al., 2015a,b; Figueiredo et al., 2016a).

Whenever the effect of sex was found to approach significance $(P<0.10)$, indicating a different intercept for at least one sex, 3 contrast statements were used to conduct all 3 pairwise comparisons of sex. Likewise, 3 contrast statements were used to conduct all 3 pairwise comparisons when the interaction between sex and the regressor $W$ was found to approach significance $(P<$ $0.10)$, indicating that at least one sex had a different slope. In the study of Bompadre et al. (2014), intact male kids slaughtered at $5 \mathrm{~kg}$ of $\mathrm{BW}$ were also considered for developing the equation for castrated male kids (for details, see Bompadre et al., 2014), and then a correction of the degrees of freedom was performed using

Table 2. Summary of statistics related to body composition of dairy goats used in this study

\begin{tabular}{|c|c|c|c|c|}
\hline Variable & $\mathrm{n}^{1}$ & Mean & $\mathrm{SD}$ & Range \\
\hline \multicolumn{5}{|c|}{ Body protein $\left(\mathrm{g} / \mathrm{kg}\right.$ of $\left.\mathrm{EBW}^{2}\right)$} \\
\hline All animals & 238 & 173 & 18.4 & 114 to 264 \\
\hline Castrated male & 73 & 173 & 16.6 & 114 to 206 \\
\hline Intact male & 94 & 178 & 18.4 & 130 to 264 \\
\hline Female & 71 & 166 & 18.1 & 123 to 214 \\
\hline \multicolumn{5}{|c|}{ Body fat (g/kg of EBW) } \\
\hline All animals & 238 & 144 & 78.7 & 21 to 390 \\
\hline Castrated male & 73 & 145 & 69.8 & 22 to 345 \\
\hline Intact male & 94 & 110 & 51.3 & 22 to 258 \\
\hline Female & 71 & 188 & 95.1 & 21 to 390 \\
\hline \multicolumn{5}{|c|}{ Body energy (kcal/kg of EBW) } \\
\hline All animals & 238 & 2,230 & 679 & 936 to 4,519 \\
\hline Castrated male & 73 & 2,213 & 648 & 936 to 4,143 \\
\hline Intact male & 94 & 1,975 & 470 & 936 to 3,330 \\
\hline Female & 71 & 2,586 & 841 & 1,086 to 4,519 \\
\hline \multicolumn{5}{|c|}{ Body ash $(\mathrm{g} / \mathrm{kg}$ of EBW $)$} \\
\hline All animals & 220 & 43 & 11.1 & 25 to 80 \\
\hline Castrated male & 55 & 40 & 7.60 & 25 to 56 \\
\hline Intact male & 94 & 48 & 12.1 & 24 to 80 \\
\hline Female & 71 & 38 & 9.50 & 25 to 60 \\
\hline \multicolumn{5}{|c|}{ Body water $(\mathrm{g} / \mathrm{kg}$ of EBW) } \\
\hline All animals & 220 & 640 & 79.8 & 416 to 809 \\
\hline Castrated male & 55 & 644 & 81.2 & 457 to 809 \\
\hline Intact male & 94 & 663 & 59.9 & 478 to 809 \\
\hline Female & 71 & 607 & 90.7 & 416 to 777 \\
\hline
\end{tabular}


the DDF option in the MODEL statement of MIXED procedure of SAS (Appendix).

Net Requirements for Growth. The coefficients to estimate net requirements for growth were obtained as the first partial derivative of the allometric equations with respect to EBW. That is, model [2] was first back-transformed to the native scale (done separately for each sex here to simplify the notation):

$$
Y=10^{B_{0}} W^{B_{1}} 10^{s} 10^{e} .
$$

The first partial derivative of this is

$$
\frac{\partial Y}{\partial W}=B_{1} 10^{B_{0}+s+e} W^{B_{1}-1} .
$$

In [4], the expectations of $s$ and $e$ are both equal to zero. Therefore, the expectation $E$ (i.e., mean value) for the derivative is

$$
E\left(\frac{\partial Y}{\partial W}\right)=B_{1} 10^{B_{0}} W^{B_{1}-1} .
$$

That is, [5] is used to estimate the mean net requirement in grams or kilocalories per kilogram of EBW gained, with the explicit understanding that either $B_{0}$ or $B_{1}$, or both, can be different across sexes.

Because of the complexity of [4] and the correlation between the estimated $B_{0}$ and $B_{1}$, the variance of $\partial Y / \partial W$ is not analytically tractable. A Monte Carlo-based simulation was used to calculate numerical estimates of the variance and confidence intervals for $\partial Y / \partial W$ (i.e., net requirements). For each sex, and for each $W$ for which a net requirement was being calculated, 10,000 simulated values of $\partial Y / \partial W$ were generated using a multivariate normal distribution for $B_{0}$, $B_{1}$, and $e$ for the error of estimation, and $B_{0}, B_{1}, s$, and $e$ for the error of prediction using the algorithm of Fan et al. (2002). This was done on the conditional values of the study effect, where the error of estimation for the requirement of a given animal among the 7 studies used in the analyses is known (what we refer to as "error of estimation"); this was also done for the general case, where the value of the effect of the study is unknown, to reflect the uncertainty around the calculated requirements when applied to an animal not in the data set (what we call the "error for prediction").

Considering that degree of maturity (i.e., the ratio between current weight and mature weight) affects body composition and, consequently, nutritional requirements (NRC, 2007), we decided to evaluate the relationship between protein or energy composition of the gain (g or kcal/kg of EBW gain) and degree of maturity according to model [6]. The degree of maturity was calculated as a ratio between EBW and mature EBW of Saanen goats, by using mature EBW of 34.9, 42.6 , and $26.0 \mathrm{~kg}$ for castrated males, intact males and females, respectively, as reported by Almeida et al. (2016):

$$
Y_{i j k}=B_{0_{i}}+B_{1_{i}} W_{i j k}+s_{j}+e_{i j k},
$$

where $Y_{i j k}$ is the value of the dependent variable (either energy in the EBW gain expressed as $\mathrm{kcal} / \mathrm{kg}$ of EBW gain in the ratio between EBW and mature EBW, or protein expressed as $\mathrm{g} / \mathrm{kg}$ of $\mathrm{EBW}$ gain in the ratio between EBW and mature EBW) for the $k$ th animal of the $i$ th sex in the $j$ th study; $B_{0_{i}}$ and $B_{1_{i}}$ are parameters to be estimated for each of the sexes $i ; s_{j}$ is the random effect of the $j$ th study $\sim N\left(0, \sigma_{s}^{2}\right)$, and $e_{i j k}$ is the residual error $\sim N\left(0, \sigma_{e}^{2}\right)$.

For some of the females and castrated males, the degree of maturity was $>1$, seeing that we excluded these data from the analysis for this approach. Then, we used data of 94 intact males, 68 castrated males, and 47 females. Outliers were removed when their normalized residuals were $>|3|$. For protein, 7 data points were removed, and for energy, 4 data points were removed. The outliers were from 4 different studies (Gomes, 2011; Bompadre et al., 2014; Almeida et al., 2015a,b; Figueiredo et al., 2016a). Monte Carlo simulation, as previously described, was also applied for this approach.

\section{RESULTS}

\section{Estimation of EBW}

The effect of sex did not approach significance for any of the parameter estimates $(P>0.10)$ in the regression equations developed for estimating EBW from BW. On the other hand, phase (suckling or weaned) affected both the intercept $(P=0.006)$ and the slope $(P<0.001)$. Hence, we used distinct equations (Eq. [7] and Eq. [8]) to estimate EBW from BW (n $=242, P<$ 0.0001 , study variance $\sigma_{s}^{2}=0.568$, residual variance $\sigma_{e}^{2}$ $=0.856)$ :

$$
\begin{aligned}
& \text { Suckling: EBW }=0.76( \pm 0.598) \\
& \quad+0.749( \pm 0.0209) \times \mathrm{BW} ; \\
& \text { Weaned: EBW }=-2.38( \pm 0.515) \\
& \quad+0.892( \pm 0.0114) \times \mathrm{BW} .
\end{aligned}
$$


Table 3. Allometric equations of $\log _{10}$ of body protein $(\mathrm{g}), \log _{10}$ of body fat $(\mathrm{g})$ and body energy $(\mathrm{kcal})$ on $\log _{10}$ $\mathrm{EBW}^{1}(\mathrm{~kg})$ of growing dairy goats

\begin{tabular}{|c|c|c|c|c|c|}
\hline \multirow[b]{2}{*}{ Item $^{2}$} & \multirow[b]{2}{*}{$\mathrm{b}_{0}$} & \multirow[b]{2}{*}{$b_{1}$} & \multirow[b]{2}{*}{$\mathrm{n}^{3}$} & \multicolumn{2}{|c|}{$P$-value ${ }^{4}$} \\
\hline & & & & $\mathrm{b}_{0}$ & $\mathrm{~b}_{1}$ \\
\hline Protein & & & & 0.084 & 0.024 \\
\hline Castrated male & $2.213 \pm 0.0289$ & $1.020 \pm 0.0220$ & 77 & & \\
\hline Intact male & $2.228 \pm 0.0244$ & $1.010 \pm 0.0184$ & 93 & & \\
\hline Female & $2.277 \pm 0.0288$ & $0.958 \pm 0.0218$ & 71 & & \\
\hline All males ${ }^{5}$ & $2.221 \pm 0.0224$ & $1.015 \pm 0.0165$ & 170 & & \\
\hline Fat & & & & $<0.001$ & $<0.001$ \\
\hline Castrated male & $1.210 \pm 0.0714$ & $1.708 \pm 0.0518$ & 78 & & \\
\hline Intact male & $1.384 \pm 0.0618$ & $1.506 \pm 0.0437$ & 93 & & \\
\hline Female & $1.053 \pm 0.0703$ & $1.873 \pm 0.0509$ & 71 & & \\
\hline Energy & & & & $<0.001$ & $<0.001$ \\
\hline Castrated male & $2.873 \pm 0.0377$ & $1.359 \pm 0.0283$ & 78 & & \\
\hline Intact male & $2.988 \pm 0.0323$ & $1.240 \pm 0.0238$ & 93 & & \\
\hline Female & $2.820 \pm 0.0377$ & $1.442 \pm 0.0281$ & 71 & & \\
\hline
\end{tabular}

${ }^{1} \mathrm{EBW}=$ empty $\mathrm{BW}$.

${ }^{2}$ The estimated study variances $\left(\sigma_{s}^{2}\right)$ and the residual variances $\left(\sigma_{e}^{2}\right)$ were, respectively, 0.000388 and 0.00140 for protein, 0.00551 and 0.00699 for fat, and 0.000956 and 0.00223 for energy.

${ }^{3}$ Number of animals used to estimate parameters.

${ }^{4} P$-value for fixed effect tests to check whether the intercept $\left(b_{0}\right)$ and the slope $\left(b_{1}\right)$ differ across the 3 sexes.

${ }^{5}$ An overall equation for males is reported because the differences in intercept and slope between castrated and intact males were not statistically significant $(P>0.10)$.

\section{Protein Requirements for Growth}

The total protein in the EBW tended to differ between sexes $(P<0.10$; Table 3$)$. Intercepts $(P=0.59)$ and slopes $(P=0.68)$ were similar between castrated and intact males. However, intercepts $(P=0.03)$ and slopes $(P=0.01)$ differed between castrated males and females, as did intercepts $(P=0.09)$ and slopes $(P=$ $0.02)$ between intact males and females. Therefore, we are reporting the parameters applicable to each sex and one general equation to all males because castrated and intact males were similar $(P>0.10$; Table 3$)$. Figure 1 illustrates the good fit of the allometric equations for body protein.

Our results showed that females and males have different $\mathrm{NP}_{\mathrm{G}}$. Therefore, 2 different equations were necessary to calculate these requirements:

$$
\begin{aligned}
& \text { All males: } \mathrm{NP}_{\mathrm{G}}=1.015 \times 10^{2.221} \times \mathrm{EBW}^{0.0150} ; \quad[9] \\
& \text { Females: } \mathrm{NP}_{\mathrm{G}}=0.9586 \times 10^{2.277} \times \mathrm{EBW}^{-0.0414} \cdot[10]
\end{aligned}
$$

Monte Carlo techniques were used to estimate the uncertainty of $\mathrm{NP}_{\mathrm{G}}$ when equations [9] and [10] were used (i.e., $\mathrm{SD}$ of $\mathrm{NP}_{\mathrm{G}}$ ). For males and females, the greatest uncertainty for $\mathrm{NP}_{\mathrm{G}}$ was at an EBW of $37.8 \mathrm{~kg}$ (corresponding to $\mathrm{BW}$ of $45 \mathrm{~kg}$ ). For males with $\mathrm{BW}$ between 5 and $45 \mathrm{~kg}, \mathrm{NP}_{\mathrm{G}}$ ranged from (mean $\left.\pm \mathrm{SD}\right) 173 \pm 3.08$ to $179 \pm 5.64 \mathrm{~g} / \mathrm{kg}$ of EBW gain (Table 4). For females with similar $\mathrm{BW}, \mathrm{NP}_{\mathrm{G}}$ was lower and ranged from 171 \pm 3.74 to $156 \pm 6.84 \mathrm{~g} / \mathrm{kg}$ of EBW gain (Table 4). When presented in units of BW as opposed to EBW, the $\mathrm{NP}_{\mathrm{G}}$ in males ranged from 156 to $150 \mathrm{~g} / \mathrm{kg}$ of $\mathrm{BW}$

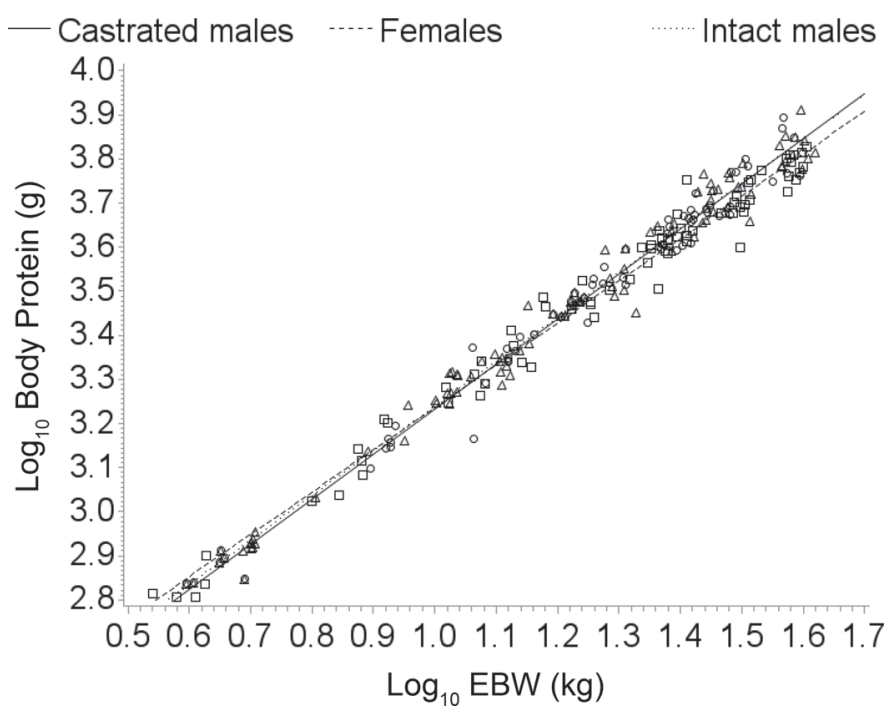

Figure 1. Relationship between $\log _{10}$ protein $(\mathrm{g})$ and $\log _{10}$ empty BW (EBW; kg) of growing dairy goats of different sexes (records of $\bigcirc$ castrated males, $\square$ females, and $\Delta$ intact males): for males, $\log _{10}$ protein $=2.221( \pm 0.0224)+1.015( \pm 0.0165) \times \log _{10}$ EBW; for females, $\log _{10}$ protein $=2.277( \pm 0.0288)+0.958( \pm 0.0218) \times \log _{10}$ EBW. The estimated study variances $\left(\sigma_{s}^{2}\right)$ and the residual variances $\left(\sigma_{e}^{2}\right)$ were 0.000388 and 0.00140 , respectively. Intercepts and slopes were different for males and females $(P=0.028$ and $P=0.006$, respectively). The observations were adjusted for the study effect. 
Table 4. Effect of sex on estimated and predicted net protein requirements ${ }^{1}$ of growing dairy goats between 5 and $45 \mathrm{~kg}$ of BW

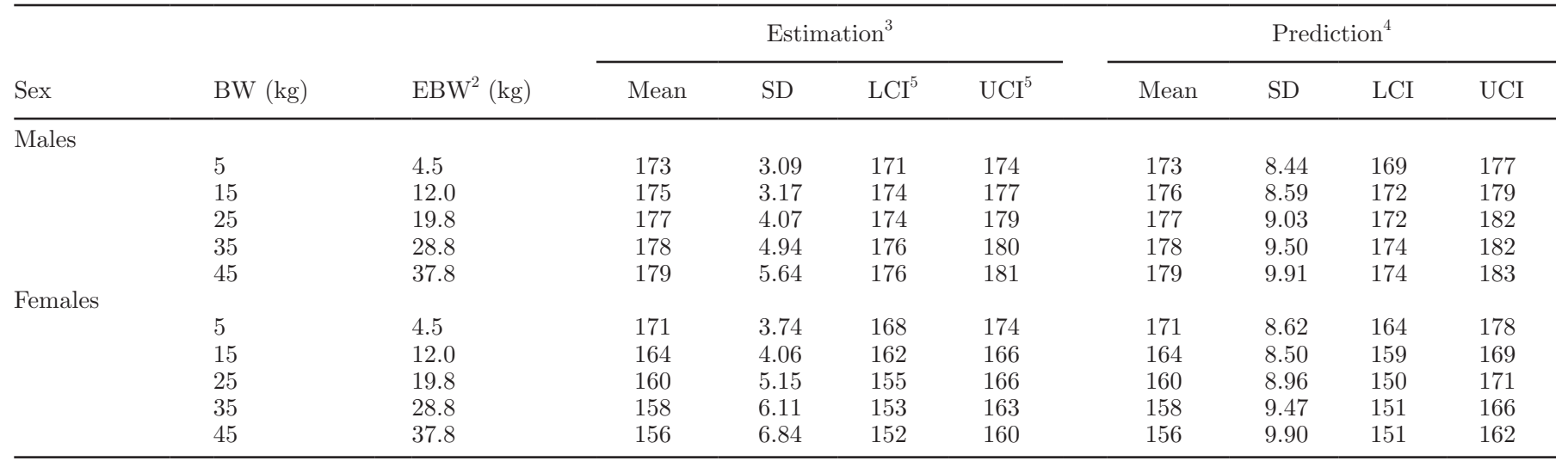

${ }^{1}$ Net protein requirements ( $\mathrm{g} / \mathrm{kg}$ of EBW gain) were calculated as the first derivative of the allometric equation. For males, net protein for gain $\left(\mathrm{NP}_{\mathrm{G}}\right)=1.015 \times 10^{2.221} \times \mathrm{EBW}^{0.015}$. For females: $\mathrm{NP}_{\mathrm{G}}=0.958 \times 10^{2.277} \times \mathrm{EBW}^{-0.0414}$.

${ }^{2} \mathrm{EBW}=$ empty BW. The values were calculated from the equation: $\mathrm{EBW}=0.76( \pm 0.597)+0.75( \pm 0.0209) \times \mathrm{BW}$ when $5<\mathrm{BW}<15 \mathrm{~kg}$, and from the equation $\mathrm{EBW}=-2.38( \pm 0.515)+0.892( \pm 0.0114) \times \mathrm{BW}$ when $\mathrm{BW} \geq 15 \mathrm{~kg}$.

${ }^{3}$ Estimation refers to the statistics for an animal within the data set used. It is conditional to the study effect. Hence, the uncertainty related to the study is not factored in.

${ }^{4}$ Prediction refers to statistics for an animal not within the data set used, for example, a future observation. It is not conditional on a known study effect. Hence, the uncertainty related to the study is factored in.

${ }^{5} \mathrm{LCI}$ and UCI $=$ lower and upper $95 \%$ confidence limit of requirement, respectively.

gain, and $\mathrm{NP}_{\mathrm{G}}$ in females ranged from 154 to $131 \mathrm{~g} / \mathrm{kg}$ of BW gain.

Table 4 compares estimated and predicted values obtained for $\mathrm{NP}_{\mathrm{G}}$. Although the estimated and predicted means of $\mathrm{NP}_{\mathrm{G}}$ (i.e., expectation) were the same, the $\mathrm{SD}$ and confidence limits were greatest when simulating an external data set (i.e., prediction, where the effect of the study is unknown).

The $\mathrm{NP}_{\mathrm{G}}$ based on degree of maturity was estimated by regressing the protein in gain on the ratio between EBW and mature EBW (Eq. [11], [12], and [13]; $\mathrm{n}=$ $\left.202 ; \sigma_{s}^{2}=156.2, \sigma_{e}^{2}=2,237\right)$.

Castrated males: $\mathrm{NP}_{\mathrm{G}}=188.8( \pm 17.4)$

$-11.2( \pm 28.7) \times$ EBW:mature EBW;

Intact males: $\mathrm{NP}_{\mathrm{G}}=185.6( \pm 13.4)$

$-4.18( \pm 24.0) \times$ EBW:mature EBW;

Females: $\mathrm{NP}_{\mathrm{G}}=153.5( \pm 21.5)$

$+25.2( \pm 30.2) \times$ EBW:mature EBW.

Sex does not affect the $\mathrm{NP}_{\mathrm{G}}$ when applying this approach $(P=0.26)$; consequently, we obtained a general model (Figure 2). The slope of this relationship was not significant in the general model $(P=0.86)$; therefore, we cannot describe this relationship based on the independent variable ratio between EBW and mature
EBW. According to this result, we verified an overall $\mathrm{NP}_{\mathrm{G}}$ of $176 \mathrm{~g} / \mathrm{kg}$ of EBW gain irrespective of degree of maturity, with an uncertainty of $\pm 12.8 \mathrm{~g} / \mathrm{kg}$ of EBW (Figure 3).

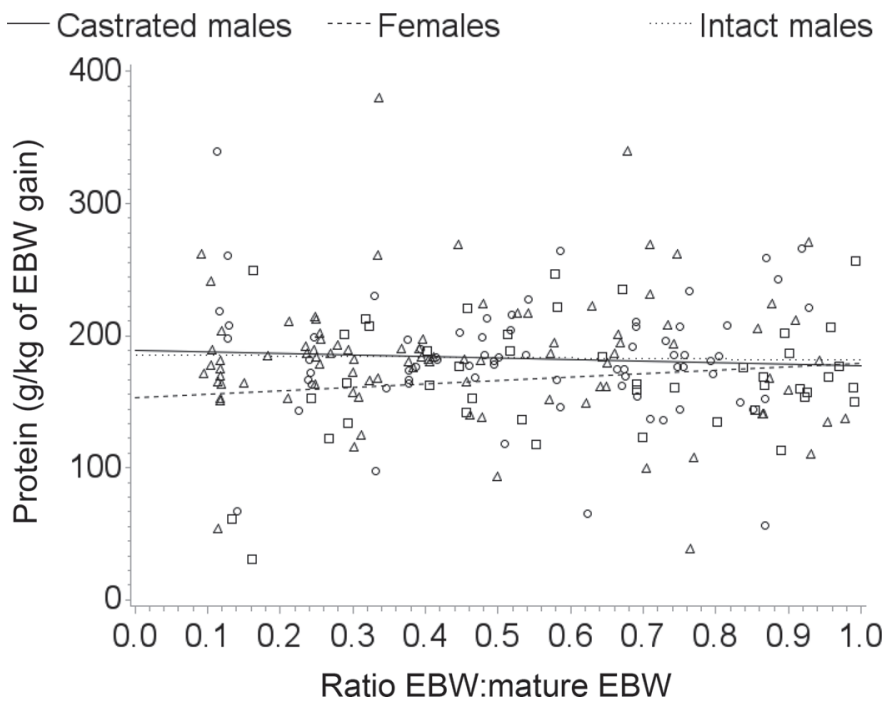

Figure 2. Relationship between protein $[\mathrm{g} / \mathrm{kg}$ of empty BW (EBW) gain] and ratio EBW:mature EBW of growing dairy goats (records of $\bigcirc$ castrated males, $\square$ females, and $\Delta$ intact males). Intercepts and slopes were similar between sexes $(P>0.05)$. The general equation was protein $=176( \pm 12.8)+3.25( \pm 19.0) \times$ ratio EBW:mature EBW. The slope was not significant $(P=0.86)$. Estimated study variances $\left(\sigma_{s}^{2}\right)$ and the residual variances $\left(\sigma_{e}^{2}\right)$ were 156.2 and 2,237 , respectively. The observations were adjusted for the study effect. 
4580

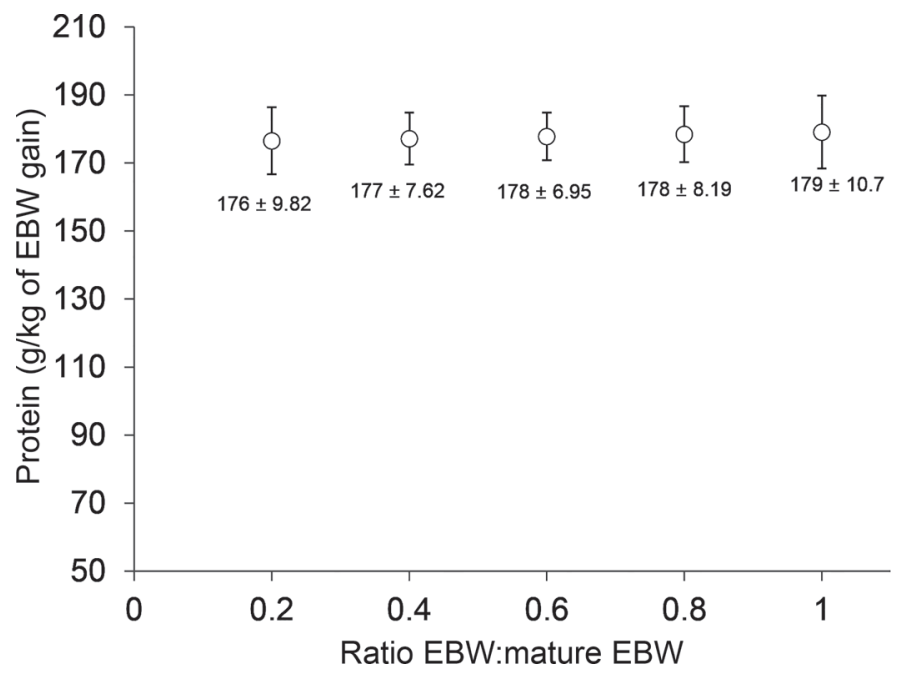

Figure 3. Net protein requirements for growth $[\mathrm{g} / \mathrm{kg}$ of empty BW (EBW) gain; mean $\pm \mathrm{SD}$ ] of growing dairy goats according to degree of maturity, calculated based on the equation protein $=176( \pm 12.8)+$ $3.25( \pm 19.0) \times$ ratio EBW:mature EBW.

\section{Energy Requirements for Growth}

The intercepts and slopes of fat content in EBW equations were different between sexes $(P<0.05)$; therefore, we report separate equations to estimate the fat content of EBW for the 3 sexes (Table 3).

The energy content in EBW differed between sexes $(P<0.001$; Table 3$)$. Intercepts of the allometric equations for energy content were similar between castrated males and females $(P=0.17)$ but the slopes were different $(P=0.008)$. Intercept $(P=0.002)$ and slopes $(P$ $<0.001)$ differed between castrated males and intact males. Intercept $(P<0.001)$ and slopes $(P<0.001)$ differed between intact males and females. Therefore, we report separate equations to estimate the energy content of EBW for the 3 sexes (Table 3). Similar to what we observed for body protein, the allometric equations for body energy on EBW (Figure 4) showed that the model presented a good fit, and the linearization of the model resulted in homoscedastic errors.

The $\mathrm{NE}_{\mathrm{G}}$ was estimated as the first partial derivative of the allometric equations for body energy on EBW. Our results showed that castrated males, intact males, and females have different $\mathrm{NE}_{\mathrm{G}}$. Therefore, we report separate equations for each of the 3 sexes:

$$
\begin{aligned}
& \text { Castrated males: } \mathrm{NE}_{\mathrm{G}}=1.359 \times 10^{2.873} \\
& \times \mathrm{EBW}^{0.359} \\
& \text { Intact males: } \\
& \mathrm{NE}_{\mathrm{G}}=1.240 \times 10^{2.988} \\
& \times \mathrm{EBW}^{0.240}
\end{aligned}
$$

Females: $\mathrm{NE}_{\mathrm{G}}=1.442 \times 10^{2.820} \times \mathrm{EBW}^{0.442}$.

As done for $\mathrm{NP}_{\mathrm{G}}$, a Monte Carlo method was used to estimate the uncertainty of $\mathrm{NE}_{\mathrm{G}}$ estimates (Table 5). Animals at $37.8 \mathrm{~kg}$ of EBW (45 kg of BW) exhibited the greatest uncertainty in $\mathrm{NE}_{\mathrm{G}}$. For castrated males, we found that $\mathrm{NE}_{\mathrm{G}}$ increased (mean $\pm \mathrm{SD}$ ) from 1,745 \pm 57.78 to $3,751 \pm 183.94 \mathrm{kcal} / \mathrm{kg}$ of EBW gain. For intact males, the increase was from $1,735 \pm 61.9$ to $2,898 \pm 149.6 \mathrm{kcal} / \mathrm{kg}$ of EBW gain. For females, the increase was from $1,857 \pm 78.7$ to $4,766 \pm 281.9 \mathrm{kcal} /$ $\mathrm{kg}$ of EBW gain in goats weighing between 5 and $45 \mathrm{~kg}$ of BW. When presented in units of BW as opposed to $\mathrm{EBW}$, the $\mathrm{NE}_{\mathrm{G}}$ for castrated males ranged from 1,570 to $3,151 \mathrm{kcal} / \mathrm{kg}$ of BW gain; for intact males, from 1,561 to $2,434 \mathrm{kcal} / \mathrm{kg}$ of $\mathrm{BW}$ gain; and for females, from 1,671 to $4,003 \mathrm{kcal} / \mathrm{kg}$ of BW gain.

Similar to $\mathrm{NP}_{\mathrm{G}}$ estimates, the uncertainty was greater in the predicted values for $\mathrm{NE}_{\mathrm{G}}$ (i.e., when the equations are applied to animals that are not part of the data set) than when the equations were applied to estimated values (i.e., animals in the data set; Table 5).

The $\mathrm{NE}_{\mathrm{G}}$ based on degree of maturity was estimated by regressing the energy in the gain on ratio between

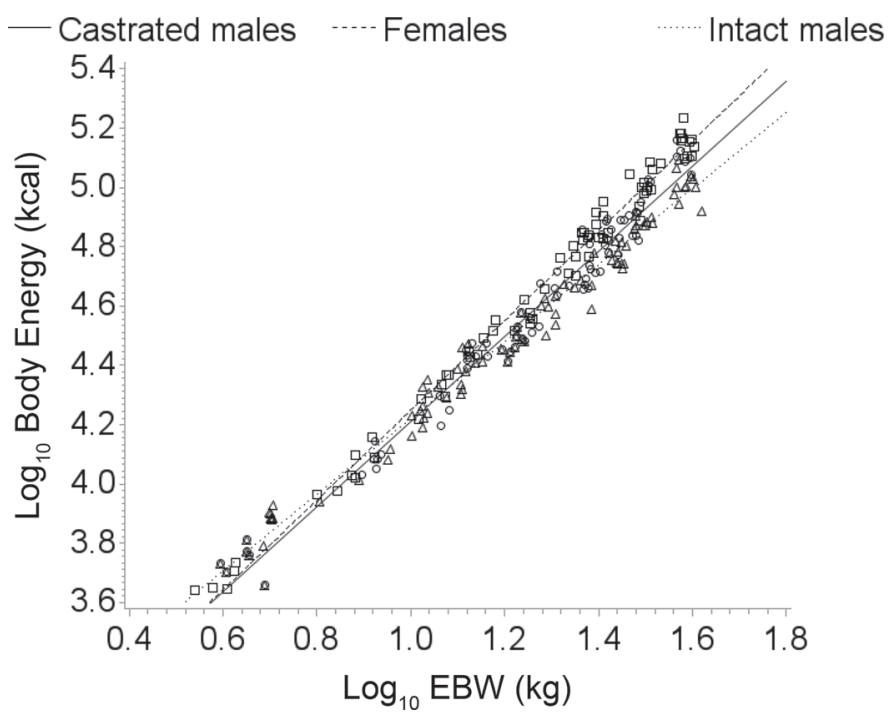

Figure 4. Relationship between $\log _{10}$ energy (kcal) and $\log _{10}$ empty BW (EBW; kg) of growing dairy goats (records of $\bigcirc$ castrated males, $\square$ females, and $\Delta$ intact males): for castrated males, $\log _{10}$ energy $=2.873( \pm 0.0377)+1.359( \pm 0.0165) \times \log _{10} \mathrm{EBW}$; for females, $\log _{10}$ energy $=2.820( \pm 0.0377)+1.442( \pm 0.0281) \times \log _{10} \mathrm{EBW}$; for intact males, $\log _{10}$ energy $=2.988( \pm 0.0323)+1.240( \pm 0.0238) \times \log _{10}$ EBW. The estimated study variances $\left(\sigma_{s}^{2}\right)$ and the residual variances $\left(\sigma_{e}^{2}\right)$ were 0.000956 and 0.00223 , respectively. Intercepts and slopes were different between sexes $(P<0.001)$. The observations were adjusted for the study effect. 
EBW and mature EBW (Eq. [17], [18] and [19]; $\mathrm{n}=$ $\left.205 ; \sigma_{s}^{2}=110,722, \sigma_{e}^{2}=459,166\right)$.

Castrated males: $\mathrm{NE}_{\mathrm{G}}=1,421( \pm 293)$

$+2,154( \pm 453) \times$ EBW:mature EBW;

Intact males: $\mathrm{NE}_{\mathrm{G}}=1,375( \pm 244)$

$+2,131( \pm 400) \times$ EBW:mature EBW;

Females: $\mathrm{NE}_{\mathrm{G}}=1,000( \pm 332)$

$+2,651( \pm 445) \times$ EBW:mature EBW.

Intercepts and slopes were similar between sexes $(P$ $>0.05)$; consequently, we generated a general model for all sexes (Figure 5). Monte Carlo techniques were used to estimate the uncertainty of $\mathrm{NE}_{\mathrm{G}}$, and the $\mathrm{NE}_{\mathrm{G}}$ increased from (mean \pm SD) $1,726 \pm 188$ to $3,575 \pm$ $197 \mathrm{kcal} / \mathrm{kg}$ of EBW gain as degree of maturity ranged from 0.2 to 1.0 (Figure 6).

\section{DISCUSSION}

The effect of the sex of an animal on its requirements for growth was evaluated in dairy goats of BW between
5 and $45 \mathrm{~kg}$. Allometric equations for estimating protein and energy contents of EBW were developed across sexes and to estimate net requirements. We found that the sex of an animal affected its protein and energy contents and, consequently, its net requirement for growth.

The allometric equation developed for protein content of EBW resulted in a slope slightly greater than 1.0 for males, leading us to conclude that body protein showed a slight but nonsignificant increase in males of increasing EBW. This means that the amount of protein increases at a similar rate to EBW in males. In contrast, for females, the allometric equation resulted in a slope significantly less than 1.0, implying that the amount of protein increases at a lower rate than EBW. Body protein decreased as BW increased only in females. This decrease occurs in response to a large addition of another constituent in the body; namely fat. Similarly, Araujo et al. (2015) reported that the protein content in the EBW of castrated dairy goats decreased as BW increased. Their findings might be related to the large range of $\mathrm{BW}$ evaluated (from $5 \pm 1.4$ to $84 \pm 6.5$ $\mathrm{kg}$ of BW), allowing them to observe fat content up to $396 \mathrm{~g} / \mathrm{kg}$ of EBW (which was similar to the maximum body fat proportion observed in females herein, $390 \mathrm{~g} /$ $\mathrm{kg}$ of EBW).

Table 5. Effect of sex on estimated and predicted net energy requirements ${ }^{1}$ of growing dairy goats between 5 and $45 \mathrm{~kg}$ of BW

\begin{tabular}{|c|c|c|c|c|c|c|c|c|c|c|}
\hline Sex & BW (kg) & $\mathrm{EBW}^{2}(\mathrm{~kg})$ & \multicolumn{4}{|c|}{ Estimation $^{3}$} & \multicolumn{4}{|c|}{ Prediction $^{4}$} \\
\hline \multicolumn{11}{|c|}{ Castrated males } \\
\hline & 15 & 12.0 & 2,481 & 70.3 & 2,440 & 2,524 & 2,486 & 191.0 & 2,373 & 2,599 \\
\hline & 25 & 19.8 & 2,971 & 104.8 & 2,899 & 3,045 & 2,976 & 237.3 & 2,812 & 3,141 \\
\hline & 35 & 28.8 & 3,401 & 145.7 & 3,319 & 3,484 & 3,406 & 284.1 & 3,246 & 3,568 \\
\hline & 15 & 12.0 & 2,197 & 78.7 & 2,161 & 2,234 & 2,201 & 176.1 & 2,120 & 2,282 \\
\hline & 25 & 19.8 & 2,479 & 102.4 & 2,363 & 2,595 & 2,483 & 205.3 & 2,251 & 2,716 \\
\hline & 35 & 28.8 & 2,713 & 127.4 & 2,612 & 2,816 & 2,718 & 233.0 & 2,532 & 2,905 \\
\hline & 45 & 37.8 & 2,897 & 149.7 & 2,813 & 2,983 & 2,903 & 256.6 & 2,758 & 3,048 \\
\hline \multicolumn{11}{|c|}{ Females } \\
\hline & 5 & 4.5 & 1,857 & 78.7 & 1,794 & 1,920 & 1,860 & 154.6 & 1,737 & 1,984 \\
\hline
\end{tabular}

${ }^{1}$ Net energy requirements (expressed in kcal of energy per kg of EBW gain) were calculated as the first derivative of the allometric equation. Castrated males: $\mathrm{NE}_{\mathrm{G}}=1.359 \times 10^{2.873} \times \mathrm{EBW}^{0.359}$. Intact males: $\mathrm{NE}_{\mathrm{G}}=1.240 \times 10^{2.988} \times \mathrm{EBW}^{0.240}$. Females: $\mathrm{NE}_{\mathrm{G}}=1.442 \times 10^{2.820} \times \mathrm{EBW}^{0.442}$. ${ }^{2} \mathrm{EBW}=$ empty BW. The values were calculated from the equation: $\mathrm{EBW}=0.76( \pm 0.597)+0.75( \pm 0.0209) \times \mathrm{BW}$ when $5<\mathrm{BW}<15 \mathrm{~kg}$, and from the equation $\mathrm{EBW}=-2.38( \pm 0.515)+0.892( \pm 0.0114) \times \mathrm{BW}$ when $\mathrm{BW} \geq 15 \mathrm{~kg}$.

${ }^{3}$ Estimation refers to the statistics for an animal within the data set used. It is conditional to the study effect. Hence, the uncertainty related to the study is not factored in.

${ }^{4}$ Prediction refers to statistics for an animal not within the data set used; for example, a future observation. It is not conditional on a known study effect. Hence, the uncertainty related to the study is factored in.

${ }^{5} \mathrm{LCI}$ and UCI $=$ lower and upper $95 \%$ confidence limit of requirement, respectively. 


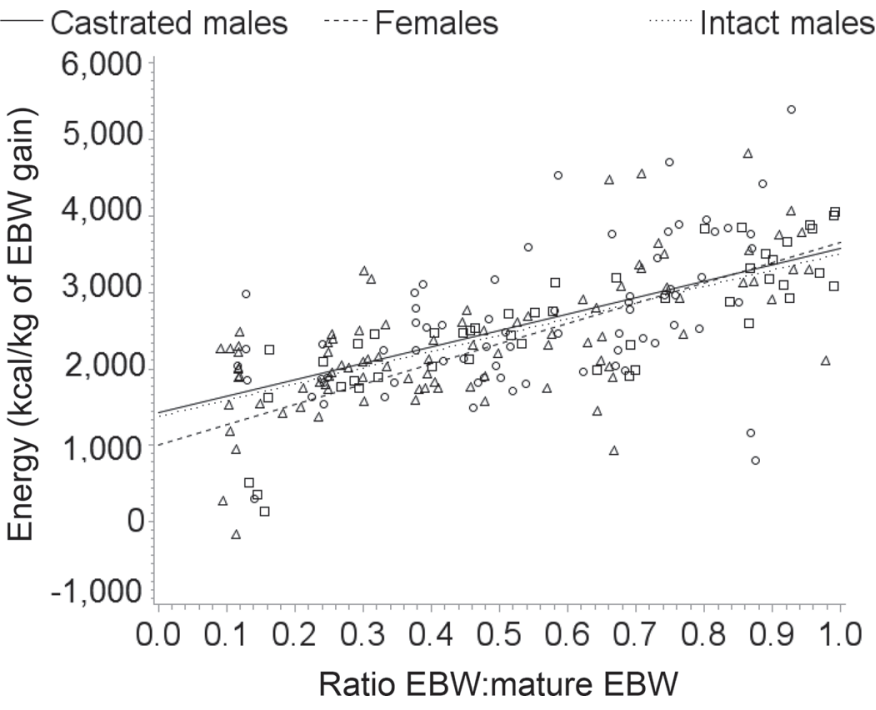

Figure 5. Relationship between energy (kcal/kg of empty BW (EBW) gain] and ratio EBW:mature EBW of growing dairy goats (records of $\bigcirc$ castrated males, $\square$ females, and $\Delta$ intact males) Intercepts and slopes were similar between sexes $(P>0.05)$. The general equation was energy $=1,265( \pm 234)+2,312( \pm 316) \times$ ratio EBW:mature EBW. The estimated study variances $\left(\sigma_{s}^{2}\right)$ and the residual variances $\left(\sigma_{e}^{2}\right)$ were 110,722 and 459,166 , respectively. The observations were adjusted for the study effect.

In this study, body protein ( $\mathrm{g} / \mathrm{kg}$ of EBW) remained constant in castrated and intact males. Body composition of male and female growing dairy goats (from 5 to $45 \mathrm{~kg}$ of BW) was detailed by Almeida et al. (2016) using the same data set used herein. They observed a similar proportion of protein in the fat-free empty body between sexes as well as a similar ratio between protein

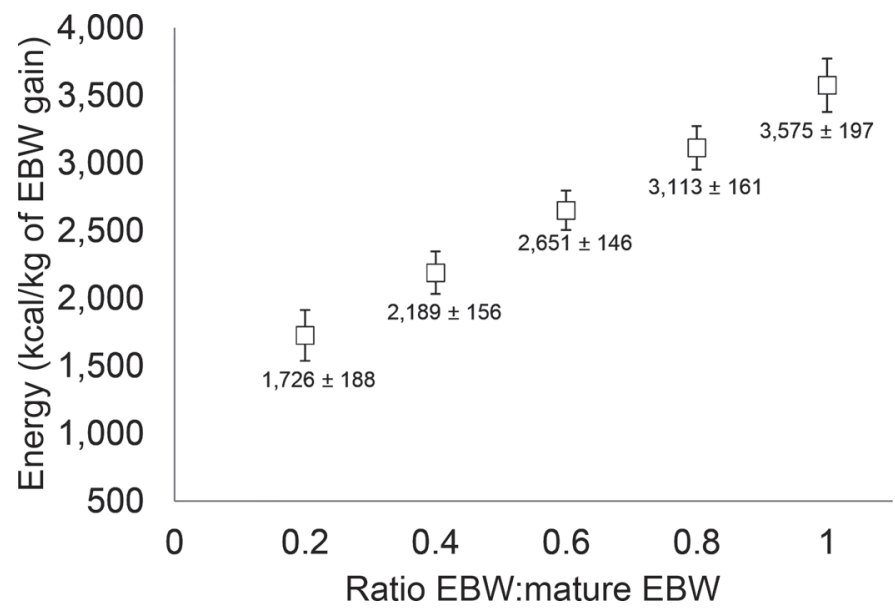

Figure 6. Net energy requirements for growth $[\mathrm{kcal} / \mathrm{kg}$ of empty BW (EBW) gain; mean $\pm \mathrm{SD}$ ] of growing dairy goats according to degree of maturity, calculated based on the equation energy $=1,265$ $( \pm 234)+2,312( \pm 316) \times$ ratio EBW:mature EBW. and fat in the empty body of castrated and intact males. That leads us to conclude that the pattern observed for protein content in males is a consequence of the proportion of other constituents in the body. In this sense, we consider that the similarity of body protein content between males is mainly because the increase of body fat was not large enough to detect any proportional difference in body protein content. Deposition of fat is delayed in relation to body growth, increasing its rate when the deposition of water, protein, and minerals is in descending phase, as observed in this study and reported in other ruminants (Geay, 1984; Lawrence et al., 2012). Therefore, we could have found differences if we had evaluated heavier goats, where the body protein content decreases with increasing $\mathrm{BW}$ due to the increase of body fat content.

In different ruminant species, as well as in pigs, males have greater lean content than females at similar BW (Berg and Butterfield, 1976; Seidman et al., 1982; Geay, 1984). When the results of independent studies included in this data set were evaluated individually, with a narrower BW range, the authors did not report differences between sexes (Almeida et al., 2015b; Figueiredo et al., 2016a). By combining data from individual animals across studies, our meta-analysis, which covers a much wider range of EBW than independent studies, enhances the power for statistical testing and parameter estimation (Sauvant et al., 2008). Thus, the number of animals used in a wide BW range of 5 to $45 \mathrm{~kg}$ was important for detecting differences between sexes.

In this study, we first expressed the protein and energy requirements per unit of EBW gain. This is because the EBW is the most adequate index of energy and nutrient content of the body, as only tissues are weighed and analyzed, enabling a more accurate comparison (Owens et al., 1995).

Regarding the uncertainty of $\mathrm{NP}_{\mathrm{G}}$, we reported an increasing standard deviation of estimates with EBW. This is a result of the multiplicative errors, and consequently, wider variation in the maximum EBW applied. The multiplicative error model assumes that the measures differ by equal proportion, and is in line with the multiplicative nature of biological processes (Kerkhoff and Enquist, 2009). Unfortunately, this variation is not taken into account in the recommendations of current feeding systems (AFRC, 1998; NRC, 2007), where requirements are commonly reported as a mean value, which might underestimate or overestimate the requirements of some animals. Assuming perfect certainty of requirements when formulating diets, could lead to sub-optimal diet for a proportion of animals. However, the uncertainty in requirements can be incorporated 
in models and can be solved using stochastic programming techniques (St-Pierre and Harvey, 1986; Yoder et al., 2014).

A direct comparison of our $\mathrm{NP}_{\mathrm{G}}$ values with the recommendations made by the most recent feeding systems is difficult due to differences in the methods used. Similar to the present meta-analysis, AFRC (1998) uses comparative slaughter technique to estimate net requirements, although the data used were insufficient to estimate the effect of sex. The AFRC data set contains predominantly data from castrated dairy goats, whose $\mathrm{NP}_{\mathrm{G}}$ ranged from 126 to $154 \mathrm{~g} / \mathrm{kg}$ of $\mathrm{BW}$ gain in goats weighing between 5 and $45 \mathrm{~kg}$, and were quite similar to our $\mathrm{NP}_{\mathrm{G}}$ estimates in females (131 to $154 \mathrm{~g} /$ $\mathrm{kg}$ of BW gain).

Body composition clearly affects growth requirements (NRC, 2007): composition of gain provides important information to understand the differences in nutritional requirements between sexes. According to Sahlu et al. (2004), the composition of gain is not reported in most publications on the nutritional requirements for goats and the values reported by NRC (2007) were mostly derived from feeding trials. Based on NRC (2007), the MP for growth $\left(\mathrm{MP}_{\mathrm{G}}\right)$ in dairy goats is $290 \mathrm{~g} / \mathrm{kg}$ of BW gain, which translates to a net requirement of $171 \mathrm{~g} /$ $\mathrm{kg}$ of BW gain (assuming an efficiency of utilization for growth of 0.59, as proposed by AFRC, 1992). Differential requirement of males versus females have not been taken into consideration in this recommendation. In general, the values we obtained for males and females in the present study were lower than the recommendations by NRC (2007), presumably due to differences in techniques used.

Even though prediction and estimation are semantically similar, there is a statistically important distinction between them. An estimate refers to a calculated value for an animal in the data set (i.e., with a realized study effect). On the other hand, a prediction is calculated for an animal not in the data set, for which the effect of the study is unknown (Fan et al., 2002). Including the effect of the study as a random factor improves the accuracy of parameter estimates in the model (StPierre, 2001). Consequently, this reduces the error in the estimated values (estimation). On the other hand, the error in prediction is larger because it applies to an animal not within the data set that is being used - a future observation, for example - where the study effect is unknown. When we evaluate the confidence limits of the estimates of $\mathrm{NP}_{\mathrm{G}}$, the uncertainty is in the range of 1 to $3 \%$ of the mean value in female goats. On the other hand, when applying the prediction to animals that are not included in the data set and the effect of the study is unknown, the uncertainty regarding the requirements increases, and is between 3 and $6 \%$ of the mean value.
The allometric equations developed for the energy and fat contents of EBW resulted in positive slopes $(>1.0)$ for all sexes. This implies that the amounts of energy and fat increase at a rate faster than EBW in growing goats. Sex is a factor that determines the composition of growth, where hormonal regulations can establish biological limits for protein and fat deposition (Byers, 1982). In response to changes in absorbed nutrients, hormonal regulation in females results in greater increase of fat in their body and consequently a greater amount of energy than in males. This is possibly because of the earlier fat deposition in abdominal tissues of females, which is an innate preparation of the female for future pregnancy (Berg and Butterfield, 1976). However, there is clearly an increase in fat deposition in castrated males as well. Sexual hormones are involved in the control of many mechanisms, and testosterone affects the secretion of growth hormone, and acts synergistically with estrogen to enhance deposition of lean tissue (Owens et al., 1993). The importance of growth hormone in modulating lipid metabolism by decreasing glucose transportation and lipogenesis was detailed by Louveau and Gondret (2004). A castrated male clearly has reduced testosterone production compared with an intact male, explaining the increase in the lipid content and adipose tissue mass of the EBW that we observed.

We found differences in energy requirement between sexes, with $\mathrm{NE}_{\mathrm{G}}$ at a given $\mathrm{EBW}$ being greater for females than for males. Likewise, castrated males had greater $\mathrm{NE}_{\mathrm{G}}$ than intact males. These are directly related to differences in body composition, fat, and energy accretion described in the allometric equations. These results regarding the effect of the sex of an animal on its $\mathrm{NE}_{\mathrm{G}}$ are consistent with recommendations in beef cattle, where the $\mathrm{NE}_{\mathrm{G}}$ of steers is greater than that of bulls and less than that of heifers (NRC, 2000). Fat is a component of EBW that undergoes greater variation throughout the life of an animal (Berg and Butterfield, 1976), which explains the greater standard deviation in $\mathrm{NE}_{\mathrm{G}}$ observed with females.

The estimated $\mathrm{NE}_{\mathrm{G}}$ for castrated males in the present study was similar to that reported by AFRC (1998) of 2.2 to $4.1 \mathrm{Mcal} / \mathrm{kg}$ of EBW gain, but without distinction between sexes in their estimation. The similarity of results may be due to the characteristics of the data set and the estimation technique used by AFRC (1998) that worked mainly with castrated males, using the comparative slaughter technique. NRC (2007) also did not incorporate a sex effect into the energy requirements for growth. In NRC (2007), the requirements are expressed in $\mathrm{ME}$ units $\left(\mathrm{ME}_{\mathrm{G}} ; 5.5 \mathrm{Mcal} / \mathrm{kg}\right.$ of $\mathrm{BW}$ gain), making comparisons to our results more difficult, because differences related to composition of gain of different sexes would directly affect the protein and fat 
deposition efficiencies. Variation in diet components and the ratio of roughage to concentrate has been reported to affect the partial efficiency of energy use for gain in lambs (Galvani et al., 2014). Therefore, energy requirements expressed in net terms should result in a more reliable estimate. Moreover, as females retain a greater proportion of energy as fat, the efficiency may be different from a bioenergetics perspective (Almeida et al., 2015a). More investigations considering ME intake would be beneficial to evaluate the efficiency of energy use for gain.

When we evaluated the confidence limits for our estimates of $\mathrm{NE}_{\mathrm{G}}$, the uncertainty fell in the range of 3 to $5 \%$ of the mean value for growing goats. On the other hand, when it was applied in animals that were not included in the data set (i.e., with unknown study effect), the uncertainty fell in the range of 5 to $9 \%$ of the mean value (prediction). The uncertainty surrounding $\mathrm{NE}_{\mathrm{G}}$ is greater than the uncertainty associated with $\mathrm{NP}_{\mathrm{G}}$, which may be related to the considerable variation of body fat content between individuals (Berg and Butterfield, 1976).

Given the body composition changes from birth to maturity, the most remarkable change in the body constituents of growing dairy goats (i.e., body fat content) is dependent on the degree of maturity at certain BW, where females reach maturity earlier than males (Almeida et al., 2016). The earlier fat deposition determines why females require more energy and less protein than males at the same BW, because animals with distinct mature weights present different patterns of growth and consequently body composition (Tedeschi et al., 2004).

Based on this fact, it is important to evaluate requirements for growth according to degree of maturity. The results of $\mathrm{NP}_{\mathrm{G}}$ and $\mathrm{NE}_{\mathrm{G}}$ based on the degree of maturity presented herein were similar between the sexes. In this sense, we were able to eliminate the effect of sex in the model because we isolated the differences in body composition that goats of different sexes showed at the same BW. The degree of maturity allowed us to confirm that a female at $26.0 \mathrm{~kg}$ of EBW had similar $\mathrm{NP}_{\mathrm{G}}$ and $\mathrm{NE}_{\mathrm{G}}$ to a castrated male weighing $34.9 \mathrm{~kg}$ of EBW or an intact male weighing $42.6 \mathrm{~kg}$ of EBW because they were at similar degrees of maturity. Therefore, they could receive similar diets considering just $\mathrm{NP}_{\mathrm{G}}$ and $\mathrm{NE}_{\mathrm{G}}$.

Although the estimates of $\mathrm{NP}_{\mathrm{G}}$ and $\mathrm{NE}_{\mathrm{G}}$ showed greater variation in the approach considering the degree of maturity than when applying the allometric equations, this new approach could be useful for extending the results of requirements for growth obtained herein to different sexes and perhaps breeds. Future studies should focus on evaluating the effect of sex on the body composition of mature goats and its consequence on the nutritional requirements and on determining whether it is still possible to use a general model across sexes to describe the requirements based on degree of maturity.

Estimates of nutritional requirements that are more accurate should lead to better assessment of diets. To our knowledge, this is the first meta-analysis aimed at quantifying the effect of sex on the energy and protein requirements for growth in dairy goats weighing between 5 and $45 \mathrm{~kg}$ of $\mathrm{BW}$, as well as considering the effect of degree of maturity. The information presented here improves our knowledge about the composition of gain across different sexes in dairy goats and should lead to improved diets for growing dairy goats.

\section{CONCLUSIONS}

Allometric equations for estimating $\mathrm{NP}_{\mathrm{G}}$ and $\mathrm{NE}_{\mathrm{G}}$ differ between sexes in growing Saanen goats. The $\mathrm{NP}_{\mathrm{G}}$ for males was greater than that for females. The $\mathrm{NE}_{\mathrm{G}}$ of castrated males was greater than that of intact males and less than that of females at similar BW. The effect of sex on the estimations of nutritional requirements for growth should be accounted for by feeding systems. Including the degree of maturity as predictor cancels out those differences across sexes in protein and energy requirements.

\section{ACKNOWLEDGMENTS}

The authors are grateful to Sao Paulo Research Foundation (FAPESP, Grant \#2014/14734-9), Conselho Nacional de Desenvolvimento Científico e Tecnológico $(\mathrm{CNPq})$, and Coordenação de Aperfeiçoamento de Pessoal de Nível Superior (CAPES, Brazil) for financial support.

\section{REFERENCES}

AFRC (Agricultural and Food Research Council). 1992. Technical Committee on Responses to Nutrients, Report No. 5. Nutritive requirements of ruminant animals: protein. Nutr. Abstr. Rev. Ser. B 62:787-835.

AFRC (Agricultural and Food Research Council). 1998. The Nutrition of Goats. CAB Int., New York, NY.

Almeida, A. K., K. T. Resende, N. St-Pierre, S. P. Silva, D. C. Soares, M. H. M. R. Fernandes, A. P. Souza, N. C. D. Silva, A. R. C. Lima, and I. A. M. A. Teixeira. 2015a. Energy requirements for growth in male and female Saanen goats. J. Anim. Sci. 93:3932-3940.

Almeida, A. K., K. T. Resende, N. St-Pierre, S. P. Silva, D. C. Soares, M. H. M. R. Fernandes, and I. A. M. A. Teixeira. 2015b. Protein requirements in male and female Saanen goats. Rev. Bras. Zootec. 44:397-404.

Almeida, A. K., K. T. Resende, L. O. Tedeschi, M. H. M. R. Fernandes, J. G. L. Regadas Filho, and I. A. M. A. Teixeira. 2016. Using body composition to determine weight at maturity of male and female Saanen goats. J. Anim. Sci. 94:2564-2571.

Araujo, R. P., R. A. M. Vieira, N. S. Rocha, M. L. C. Abreu, L. S. Glória, N. M. Rohem Júnior, and A. M. Fernandes. 2015. Long- 
term growth of body, body parts and composition of gain of dairy goat wethers. J. Agric. Sci. 153:1321-1340.

Berg, R. T., and R. M. Butterfield. 1976. New Concepts of Cattle Growth. Macarthur Press, Sydney, Australia.

Blaxter, K. L., and J. L. Clapperton. 1965. Prediction of amount of methane produced by ruminants. Br. J. Nutr. 19:511-522.

Bompadre, T. F., O. B. Neto, A. N. Mendonca, S. F. Souza, D. Oliveira, M. H. Fernandes, C. J. Harter, A. K. Almeida, K. T. Resende, and I. A. M. A. Teixeira. 2014. Energy requirements in early life are similar for male and female goat kids. Asian-australas. J. Anim. Sci. 27:1712-1720.

Byers, F. M. 1982. Nutritional factors affecting growth of muscle and adipose tissue in ruminants. Fed. Proc. 41:2562-2566.

Etheridge, R. D., G. M. Pesti, and E. H. Foster. 1998. A comparison of nitrogen values obtained utilizing the Kjeldahl nitrogen and Dumas combustion methodologies (Leco CNS 2000) on samples typical of an animal nutrition analytical laboratory. Anim. Feed Sci. Technol. 73:21-28.

Fan, X., A. Felsovalyi, S. A. Sivo, and S. C. Keenan. 2002. SAS for Monte Carlo Studies: A Guide for Quantitative Researchers. SAS Inst. Inc., Cary, NC.

FAOStat. 2015. Statistical basis. Accessed Aug. 17, 2015. http:// faostat3.fao.org/download/Q/QL/S.

Ferreira, A. C. D., E. A. Yáñez, A. N. Medeiros, K. T. Resende, J. M. Pereira Filho, M. H. M. R. Fernandes, A. K. Almeida, and I. A. M. A. Teixeira. 2015. Protein and energy requirements of castrated male Saanen goats. Small Rumin. Res. 123:88-94.

Figueiredo, F. O. M., T. T. Berchielli, K. T. Resende, H. F. B. Gomes, A. K. Almeida, N. K. Sakomura, and I. A. M. A. Teixeira. 2016b. Energy requirements for growth of pubertal female Saanen goats. J. Anim. Physiol. Anim. Nutr. (Berl.) 100:294-300.

Figueiredo, F. O. M., R. F. Leite, N. R. St-Pierre, K. T. Resende, A. K. Almeida, A. P. Souza, and I. A. M. A. Teixeira. 2016a. Energy and protein requirements of weaned male and female Saanen goats. J. Anim. Physiol. Anim. Nutr. https://doi.org/10.1111/jpn.12539.

Galvani, D. B., A. V. Pires, I. Susin, V. N. Gouvêa, A. Berndt, L. J. Chagas, J. R. R. Dórea, A. L. Abdalla, and L. O. Tedeschi. 2014. Energy efficiency of growing ram lambs fed concentrate-based diets with different roughage sources. J. Anim. Sci. 92:250-263.

Geay, Y. 1984. Energy and protein utilization in growing cattle. J. Anim. Sci. 58:766-778.

Gomes, H. F. B. 2011. Composição corporal e exigências nutricionais de caprinos Saanen machos dos 30 aos $45 \mathrm{~kg}$. MS Thesis. Sao Paulo State University, Sao Paulo, Brazil.

Herring, M. J., P. M. Oskui, S. L. Hale, and R. A. Kloner. 2013. Testosterone and the cardiovascular system: A comprehensive review of the basic science. J. Am. Heart Assoc. 2:e00071.

Kerkhoff, J. A., and B. J. Enquist. 2009. Multiplicative by nature: Why logarithmic transformation is necessary in allometry. J. Theor. Biol. 257:519-521.
Lawrence, T., V. Fowler, and J. Novakofski. 2012. Growth of farm animals. Wallingford, UK, CABI

Lofgreen, G. P., and W. N. Garrett. 1968. A system for expressing net energy requirements and feed values for growing and finishing beef cattle. J. Anim. Sci. 27:793-806.

Louveau, I., and F. Gondret. 2004. Regulation of development and metabolism of adipose tissue by growth hormone and the insulinlike growth factor system. Domest. Anim. Endocrinol. 27:241-255.

Medeiros, A. N., K. T. Resende, I. A. M. A. Teixeira, M. J. Araújo, E. A. Yáñez, and A. C. D. Ferreira. 2014. Energy requirements for maintenance and growth of male Saanen goat kids. Asian-australas. J. Anim. Sci. 27:1293-1302.

NRC. 2000. Nutrient Requirements of Beef Cattle. 7th rev. ed. Natl Acad. Press, Washington, DC.

NRC. 2007. Nutrient Requirements of Small Ruminants: Sheep, Goats, Cervids, and New World Camelids. 1st rev. ed. Natl. Acad. Press, Washington, DC.

Owens, F. N., P. Dubeski, and C. F. Hanson. 1993. Factors that alter the growth and development of ruminants. J. Anim. Sci. 71:3138 3150.

Owens, F. N., D. R. Gill, D. S. Secrist, and S. W. Coleman. 1995. Review of some aspects of growth and development of feedlot cattle. J. Anim. Sci. 73:3152-3172.

Sahlu, T., A. L. Goetsch, J. Luo, I. V. Nsahlai, J. E. Moore, M. L. Galyean, F. N. Owens, C. L. Ferrel, and Z. B. Johnson. 2004 Nutrient requirements of goats: Developed equations, other considerations and future research to improve them. Small Rumin. Res. 53:191-219.

Sauvant, D., P. Schmidely, J. J. Daudin, and N. R. St-Pierre. 2008. Meta-analyses of experimental data in animal nutrition. Animal 2:1203-1214.

Seidman, S. C., H. R. Cross, R. R. Oltjen, and B. D. Schanbaher. 1982. Utilization of the intact male for red meat production: A review. J. Anim. Sci. 55:826-840.

St-Pierre, N. R. 2001. Invited review: Integrating quantitative findings from multiple studies using mixed model methodology. J. Dairy Sci. 84:741-755.

St-Pierre, N. R., and W. R. Harvey. 1986. Incorporation of uncertainty in composition of feeds into least-cost ration models. 2. Joint chance constrained programming. J. Dairy Sci. 69:3063-3074.

Tedeschi, L. O., D. G. Fox, and P. J. Guiroy. 2004. A decision support system to improve individual cattle management. 1. A mechanistic, dynamic model for animal growth. Agric. Syst. 79:171-204.

Yoder, P. S., N. R. St-Pierre, and W. P. Weiss. 2014. A statistical filtering procedure to improve the accuracy of estimating population parameters in feed composition databases. J. Dairy Sci. 97:5645-5656. 


\section{APPENDIX}

\section{Procedure for a Linear Analysis Using SAS}

Allometric equations were developed for body contents (protein, fat, or energy) as dependent variables and EBW as the allometric predictor. Parameters estimates were obtained using PROC MIXED of SAS (SAS Institute Inc., Cary, NC) and RANDOM effect of the study. A correction of the degrees of freedom was performed using the DDF option in the MODEL statement of MIXED procedure. Whenever the effect of sex was found to approach significance $(P<0.10)$, indicating a different intercept for at least one sex, 3 CONTRAST statements were used to conduct all 3 pairwise comparisons of sex. The SAS code used in this analysis is presented below:

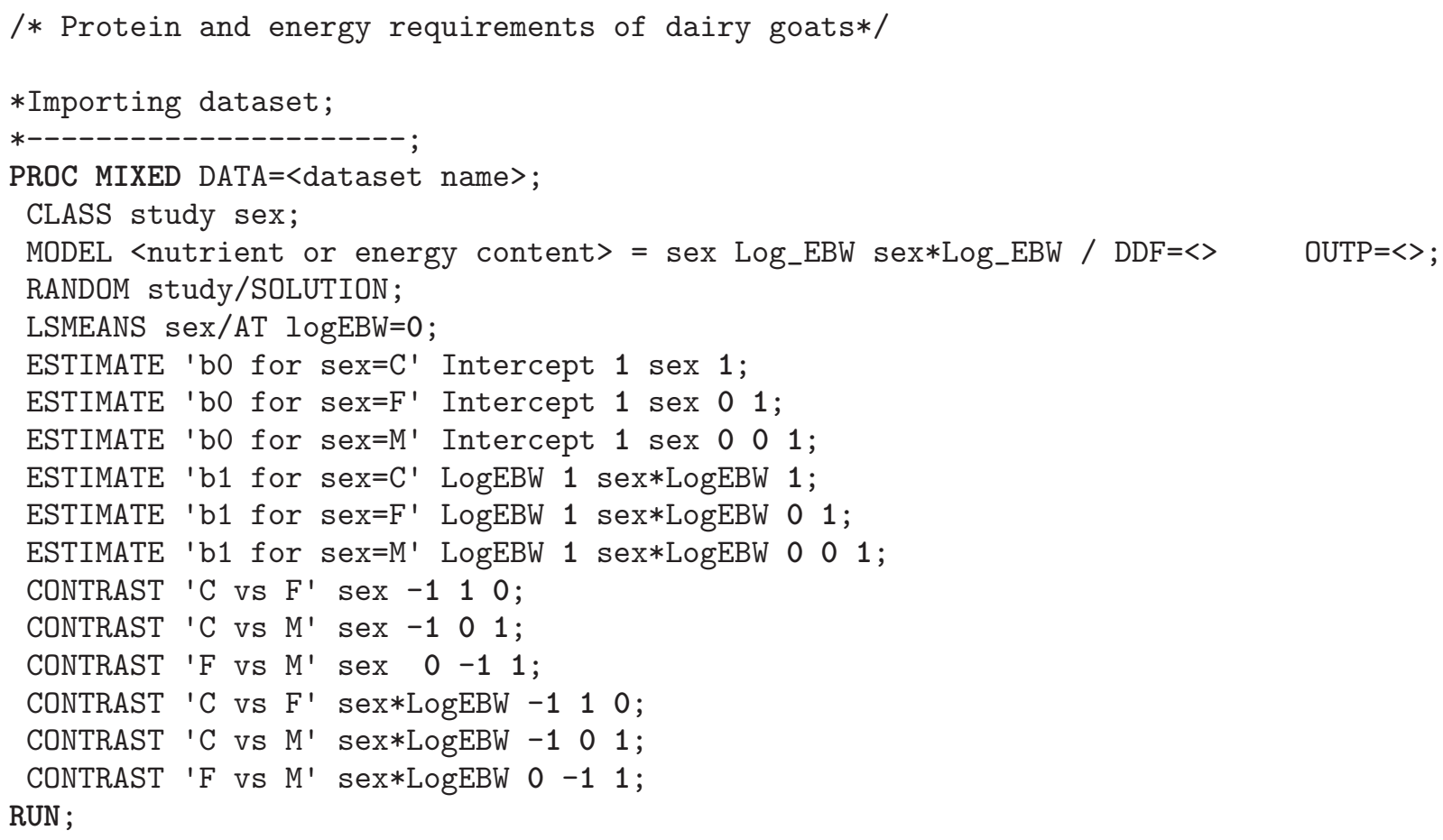

